\title{
PERWUJUDAN KEADILAN RESTORATIF DALAM SISTEM PERADILAN PIDANA ANAK MELALUI DIVERSI
}

\author{
Kristina Agustiani Sianturi \\ Kantor Wilayah Kementerian Hukum dan HAM SumateraUtara \\ E-mail: tina_pcsharoon@yahoo.com
}

\begin{abstract}
Every year, children in conflict with the law increases so it is needed to handle an alternative in the way to enforce restorative justice. Bill Number 11 of 2012 concerning Juvinele Justice System which is accomodated to handle Juvenile Deliquency for diversion. This regulation defines diversion is the transfer of the settlement of the child to the criminal justice process outside the criminal justice process. Diversion obligates to be done by officers started from police investigator, public prosecutor until judge. The important of handling of diversion process for children in conflict with the law needed a commitment for every single officers to apply diversion process. On the other hand, education and training should be given to every officers especially police investigator, public prosecutor even judge relates handling children in conflict with the law.
\end{abstract}

\section{Kata Kunci: Diversi, Peradilan Anak, Keadilan Restoratif}

\section{A. Latar Belakang}

Anak merupakan amanah dan karunia dari Tuhan Yang Maha Esa yang memiliki harkat dan martabat seutuhnya. Keberlangsungan suatu bangsa tidak dapat dipisahkan dari perkembangan anak yang merupakan generasi muda penerus bangsa. Rhona K.M Smith menyatakan bahwa keseluruhan instrumen HAM internasional justru berada pada jantung hak-hak anak (Muhtaj 2009: 225). Negara Kesatuan Republik Indonesia yang merupakan negara hukum juga menjamin kesejahteraan tiap warga negaranya, termasuk perlindungan terhadap hak anak meliputi hak atas kelangsungan hidup, tumbuh dan berkembang serta berhak atas perlindungan dari kekerasan dan diskriminasi sebagaimana diamanatkan dalam Undang Undang Dasar Negara Republik Indonesia Tahun 1945.

Jaminan perlindungan hak anak ini dikuatkan melalui ratifikasi konvensi internasional tentang Hak Anak yaitu pengesahan Konvensi Hak Anak melalui Keputusan Presiden Nomor 36 Tahun 1990 tentang Pengesahan Convention On 
The Rights Of The Child (Konvensi Tentang Hak-Hak Anak). Perlindungan ini juga dituangkan dalam Undang-undang Nomor 23 Tahun 2002 tentang Perlindungan Anak sebagaimana yang telah diubah dengan Undang-Undang Nomor 35 Tahun 2014 tentang Perubahan Atas Undang-undang Nomor 23 Tahun 2002 tentang Perlindungan Anak. Kesemuanya ini mengandung prinsip-prinsip perlindungan anak yaitu perlakuan bebas dari diskriminasi, kelangsungan hidup dan tumbuh kembang anak, kepentingan terbaik bagi anak, penghargaan terhadap pendapat anak serta perlindungan atas perampasan kemerdekaan dan pemidanaan sebagai upaya terakhir.

Sehubungan berlakunya peraturan perundang-undangan tersebut di atas, maka dalam sistem peradilan pidana anak (juvenile justice system), maka polisi sebagai institusi formal yang pertama kali melakukan penanganan, sangat menentukan apakah anak akan dibebaskan atau diproses lebih lanjut pada tingkat tingkat kejaksaan, dan selanjutnya pada tingkat kedua, yaitu jaksa juga akan menentukan apakah anak akan dibebaskan atau diproses ke pengadilan anak. Terakhir adalah Pengadilan Anak, akan menentukan pula apakah anak akan ditempatkan dalam pilihan-pilihan, mulai dari dibebaskan sampai dimasukkan dalam institusi penghukuman.

Hal yang perlu diperhatikan bahwa pada setiap tingkatan penanganannya (kepolisian, kejaksaan dan pengadilan), maka pendekatan kesejahteraan harus dapat dijadikan sebagai dasar filosofi penanganan terhadap pelanggaran hukum usia anak. Pada prinsipnya pendekatan ini didasari 2 (dua) faktor yaitu:

1. Anak-anak dianggap belum mengerti benar kesalahan yang telah diperbuat, sehingga sudah sepantasnya diberikan pengurangan hukuman, serta pembedaan pemberian hukuman bagi anak-anak dengan orang dewasa

2. Bila dibandingkan dengan orang dewasa, anak-anak diyakini lebih mudah dibina dan disadarkan.

Dasar filosofis seperti diuraikan di atas hendaknya selalu dijadikan pertimbangan dalam penanganan anak yang berhadapan dengan hukum, karena dewasa ini, sering terdengar bahkan menyaksikan sendiri anak yang berhadapan dengan hukum (selanjutnya disingkat $\mathrm{ABH}$ ) baik yang melibatkan anak sebagai 
korban, maupun pelaku tindak pidana. Kasus Muhammad Azwar alias Raju di Pengadilan Negeri Stabat merupakan salah satu kasus yang menghebohkan pelaksanaan sistem peradilan pidana anak di Indonesia. Selain itu, kasus Ardiansyah, siswa SDN 07 Jalan Pelita Kebayoran Lama Jakarta yang terenggut nyawanya setelah terjadi perkelahian dengan teman sekelasnya. Hal ini melibatkan anak sebagai korban dan juga sebagai pelaku tindak pidana yang memerlukan tindakan khusus dalam penanganannya.

Saat ini, Indonesia hanya memiliki 20 Lembaga Pemasyarakatan Khusus Anak yang tersebar di seluruh Indonesia. Data Direktorat Bina Bimbingan Kemasyarakatan dan Pengentasan Anak Direktorat Jenderal Pemasyarakatan menyebutkan bahwa tercatat ada 3.276 anak yang berkonflik dengan hukum dengan 59,31\% diantaranya terpaksa harus berbagi tempat dengan warga binaan dewasa (LPKA, www.kemenkumhan.go.id, diakses pada tanggal 5 Maret 2016).

Penempatan anak bersama dengan warga binaan dewasa akan berdampak kurang baik terhadap tumbuh kembang anak baik secara fisik maupun psikis oleh karena itu diperlukan adanya alternatif lain agar anak yang berhadapan dengan hukum dapat lebih diminimalisir penanganan perkaranya sampai ke pengadilan yang pada akhirnya menempatkan anak bersama dengan warga binaan dewasa karena keterbatasan Lembaga Pemasyarakatan Khusus Anak di Indonesia. Merujuk pada prinsip perlindungan anak yang mengutamakan kepentingan terbaik bagi anak maka diperlukan proses penyelesaian perkara anak di luar mekanisme pidana atau biasa disebut diversi sebagaimana diamanatkan oleh Undang-Undang Nomor 11 Tahun 2012 tentang Sistem Peradilan Pidana Anak (selanjutnya disebut UU SPPA).

Berdasarkan Pasal 7 UU SPPA, ditentukan bahwa diversi hanya dapat dilaksanakan kepada anak yang diancam dengan pidana penjara di bawah 7 (tujuh) tahun, dan bukan merupakan pengulangan tindak pidana (residive). Hal ini sangat perlu diperhatikan untuk memperkecil potensi pemaksaan dan intimidasi pada semua tahap proses diversi. Seorang anak tidak boleh merasa tertekan atau ditekan agar menyetujui program-program diversi. Kesepakatan diversi harus mendapatkan persetujuan korban dan/atau keluarga anak korban, serta kesediaan 
anak dan keluarganya, kecuali untuk tindak pidana yang berupa pelanggaran, tindak pidana ringan, tindak pidana tanpa korban, atau nilai kerugian korban tidak lebih dari nilai upah minimum provinsi setempat.

Terkait dengan pelaksanaan diversi, maka persoalan yang dapat saja muncul apabila kesepakatan diversi tidak dilaksanakan, sementara perkara tersebut telah dihentikan prosesnya, misalnya pelaku harus membayar sejumlah ganti kerugian kepada korban, tetapi pelaku kemudian tidak mampu membayar, apakah perkara tersebut dapat dibuka kembali proses hukumnya. Berdasarkan ketentuan Pasal 13 huruf b UU SPA, menyatakan bahwa proses peradilan dilanjutkan jika kesepakatan diversi tidak dilaksanakan. Pasal 14 ayat (3) UU SPA menentukan pula bahwa dalam hal kesepakatan diversi tidak dilaksanakan dalam waktu yang ditentukan, Pembimbing Kemasyarakatan segera melaporkannya kepada pejabat yang bertanggung jawab sebagaimana dimaksud pada ayat (1), selanjutnya dalam ayat (4) ditentukan bahwa pejabat yang bertanggung jawab sebagaimana dimaksud pada ayat (3) wajib menindaklanjuti laporan dalam waktu paling lama 7 (tujuh) hari. Atas dasar ini Penulis tertarik untuk membahas lebih lanjut, tetapi dibatasi hanya mengenai pelaksanaan diversi dalam mewujudkan keadilan restoratif, serta peran masyarakat dalam rangka mendukung pelaksanaan diversi pada sistem peradilan pidana anak.

\section{B. Metode Penelitian}

Sifat penelitian terdiri dari 3 (tiga) jenis yaitu eksploratoris, deskriptif, dan eksplanatoris. Suatu penelitian deskriptif dimaksudkan untuk memberikan data yang seteliti mungkin tentang manusia, keadaan atau gejala-gejala lainnya (Soerjono Soekanto 1986: 9). Menurut Bambang Sungguno (1998: 38) dikatakan bahwa deskriptif berarti analisis data bersifat deduktif berdasarkan teori atau konsep yang bersifat umum diaplikasikan untuk menjelaskan tentang seperangkat data atau menunjukkan komparasi/hubungan seperangkat data dengan seperangkat data lainnya. Sesuai dengan pembagian jenis penelitian berdasarkan sifatnya seperti ini, maka penelitian ini bersifat deskriptif, maksudnya untuk memberikan gambaran atau keadaan hukum tentang pelaksanaan diversi untuk dapat mewujud- 
kan keadilan restoratif, serta peran masyarakat dalam rangka mendukung pelaksanaan diversi pada sistem peradilan pidana anak.

Penelitian ini menggunakan data sekunder, baik berupa bahan hukum primer, bahan hukum sekunder maupun bahan hukum tertier, oleh sebab itu dapat disebut penelitian hukum normatif atau penelitian hukum kepustakaan (Soerjono Soekanto dan Sri Mamudji, 2003: 14). Sesuai dengan ruang lingkup masalah yang diteliti, maka pendekatan yang digunakan dalam penelitian ini adalah pendekatan perundang-undangan.

Analisis terhadap data yang terkumpul dilakukan secara yuridis kualitatif. Menurut Farouk Muhammad dan H. Djaali (2005: 93) dijelaskan bahwa analisis kualitatif dapat diartikan sebagai suatu kegiatan yang mengacu pada penelaahan atau pengujian yang sistematik mengenai suatu hal dalam rangka menentukan bagian-bagian, hubungan di antara bagian dan hubungan bagian dalam keseluruhan. Analisis yuridis kualitatif yang dimaksudkan dalam penelitian ini difokuskan pada pelaksanaan diversi dalam mewujudkan keadilan restoratif, serta konsep peran masyarakat dalam rangka mendukung pelaksanaan diversi.

\section{Hasil Penelitian dan Analisis}

\section{Penyelesaian sengketa anak berhadapan dengan hukum}

Sistem peradilan pidana adalah sistem dalam suatu masyarakat untuk menanggulangi masalah kejahatan. Menanggulangi berarti usaha untuk mengendalikan kejahatan agar berada dalam batas-batas toleransi masyarakat. Menurut Romli Atmasasmita sebagaimana dikutip Marbun (2015: 18), dikatakan bahwa sistem peradilan pidana dapat dilihat dari berbagai sudut pendekatan, yaitu:

a. Pendekatan normatif yang memandang keempat aparatur (kepolisian, kejaksaan, pengadilan dan lembaga pemasyarakatan) sebagai institusi pelaksana peraturan perundang-undangan yang berlaku sehingga keempat aparatur tersebut merupakan bagian yang tak terpisahkan dari sitem penegakan hukum semata-mata.

b. Pendekatan manajemen atau administratif yang memandang keempat aparatur penegak hukum (kepolisian, kejaksaan, pengadilan dan lembaga 
pemasyarakatan) sebagai suatu organisasi manajemen yang memiliki mekanisme kerja, baik yang bersifat horizontal maupun yang bersifat vertikal sesuai dengan struktur organisasi yang berlaku dalam organisasi tersebut. Sitem yang digunakan adalah sistem administrasi; dan

c. Pendekatan sosial yang memandang keempat aparatur penegak hukum (kepolisian, kejaksaan, pengadilan dan lembaga pemasyarakatan) merupakan bagian yang tidak terpisahkan dari suatu sitem sosial sehingga masyarakat secara keseluruhan ikut bertanggung jawab atas keberhasilan atau ketidakberhasilan dari keempat aparatur penegak hukum tersebut dalam melaksanakan tugasnya, dan sistem yang digunakan adalah sistem sosial

Dalam proses peradilan pidana umum, seseorang yang telah melakukan tindak pidana terhadapnya akan dilakukan penyelidikan oleh pihak kepolisian bila ada pengaduan atau tertangkap tangan melakukan tindak pidana. Berdasarkan hasil penyelidikan, apabila seseorang terbukti bersalah maka akan dilakukan penangkapan dan penyidikan lebih lanjut yaitu serangkaian tindakan penyidik dalam hal dan menurut cara yang diatur dalam undang-undang ini untuk mencari serta mengumpulkan bukti yang dengan bukti itu membuat terang tentang tindak pidana yang terjadi dan guna menemukan tersangkanya.

Serangkaian tindakan penyidikan dilakukan guna dijadikan berkas perkara untuk dapat diserahkan kepada kejaksaan sebagai penuntut umum dalam persidangan, tetapi proses peradilan pidana bagi anak yang berhadapan dengan hukum hendaknya dibedakan dengan proses peradilan pidana umum mengingat kondisi psikologis anak yang belum memadai dan perlu mendapat perlindungan dari pemerintah (Mualimin 2013).

Beberapa fakta menarik dalam penjara yang secara umum berlaku di semua negara dipaparkan oleh Jim Consedine (1995: 30) di antaranya orang yang paling banyak mengisi penjara adalah orang miskin dan lemah, penjara menyebabkan kenaikan tingkat kriminalitas karena negara adalah tempat untuk belajar segala jenis kejahatan, penjara menyebabkan tahanan menjadi brutal, penjara dapat merusak hubungan baik antara pelaku dengan keluarganya begitu juga dengan masyarakat, penjara adalah tempat maraknya narkoba dan obat 
terlarang lain, efek jera adalah sebuah mitos karena walaupun ancaman hukuman tindak pidana terus ditingkatkan, angka kriminalitas tetap naik dan akhirnya penjara juga menyebabkan biaya tinggi akibat tingginya penyelenggaraan kehidupan dan pemeliharaan gedung penjara yang mahal.

Sebagian besar peraturan yang berkaitan dengan penanganan $\mathrm{ABH}$ pada dasarnya telah berupaya menerapkan keadilan restoratif walaupun penerapannya belum secara komprehensif. Undang-undang Nomor 3 Tahun 1997 tentang Pengadilan Anak juga mengandung unsur-unsur keadilan restoratif yang berbeda dengan prosedur peradilan biasa seperti pada saat sebelum sidang dibuka, hakim akan memerintahan agar pembimbing kemasyarakatan menyampaikan laporan hasil penelitian kemasyakatan mengenai anak yang bersangkutan. Menurut Dewi dan Syukur (2011: 15), dikatakan bahwa hakim akan mendapatkan penjelasan yang lebih komprehensif dalam proses persidangan yang mengedepankan kepentingan terbaik bagi anak (for the best interest of the child)

Dalam praktiknya unsur-unsur keadilan restoratif itu tidak berjalan dengan baik karena beberapa kendala yang saling terkait satu sama lain hingga menyulitkan upaya perlindungan hak anak. Pengadilan anak di Indonesia juga masih melakukan pelanggaran atas hak-hak anak yang tercermin pada tindakan pengadilan diantaranya masih dijumpai adanya tuntutan hukuman mati terhadap kasus anak, belum terpenuhinya hak anak untuk didampingi pengacara, orangtua dan petugas dari Balai Pemasyarakatan, serta masih adanya perampasan kemerdekaan anak yang tidak sah karena anak sipil ditempatkan bersama-sama dengan anak negara dan anak pidana yaitu anak-anak yang ditempatkan di lembaga pemasyarakatan karena diakui secara hukum telah melakukan tindak pidana.

Penanganan anak yang berkonflik dengan hukum tidak harus menggunakan sarana nonpenal (misalnya diversi) atau menggunakan hukum pidana (sarana penal), tetapi keduanya dapat dilakukan secara berurutan, yaitu mengutamakan diversi (jika memenuhi persyaratan diversi), dan jika upaya tersebut gagal maka akan diberlakukan sistem peradilan pidana bagi anak. Secara umum, pemberlakuan sistem peradilan pidana untuk penyelesaian perkara pidana 
dapat berdampak buruk bagi anak, terutama pemberian "stigma jahat" pada anak (stigmatisasi atau labelisasi), dan terjadinya kebiasaan-kebiasaan buruk di lembaga pemasyarakatan (LAPAS) yang kemudian dipraktikkan lagi oleh anak di luar LAPAS, bahkan pengulangan tindak pidana yang lebih serius akibatnya. Salah satu penyebabnya adalah adanya kontak langsung dengan penegak hukum yang dapat membuat anak frustrasi.

Para ahli di bidang psikologi, hukum, etimologi kriminal, kriminologi, pendidikan, dan penologi selalu mencari jalan terbaik bagi anak, korban, dan kepentingan masyarakat, dan mewacanakan pendekatan keadilan restoratif sebagai alternatif pemikiran untuk mengurangi kelemahan teori pemidanaan retributif, teori prevensi maupun teori gabungan. Keadilan restoratif merupakan suatu ide dan gerakan yang mengedepankan keadilan dalam perspektif pelaku dan keluarganya, korban dan keluarganya, masyarakat, dan pemangku kepentingan dalam rangka pemulihan keadaan masing-masing (Widodo. http://id.portalgaruda. org. diakses pada tanggal 5 Maret 2016).

Konsepsi pemikiran keadilan restoratif (restorative justice) menjadi salah satu upaya menjauhkan anak dari sistem peradilan pidana yang tidak perlu. Pendekatan ini mengutamakan penyelesaian tindak pidana di luar peradilan pidana. Pendekatan tersebut bukan hanya pada anak, melainkan juga pada orang dewasa (misalnya pencurian ringan, penggelapan ringan, perbuatan curang penipuan ringan), maupun anak-anak. Bahkan di beberapa negara maju, korporasi yang melakukan tindak pidana dapat juga diselesaikan dengan pendekatan keadilan restoratif. Keadilan restoratif adalah cara menanggapi perilaku kriminal dengan cara menyeimbangkan antara kebutuhan masyarakat, dengan korban dan pelaku. Ini merupakan konsep yang terus berkembang dan dapat menimbulkan interpretasi yang berbeda di negara yang berbeda (Widodo. http://id.portalgaruda. org. diakses pada tanggal 5 Maret 2016).

\section{Perubahan paradigma sistem peradilan pidana anak}

Secara teoretis, sistem peradilan pidana anak di Indonesia wajib mengutamakan kepentingan yang terbaik bagi anak dan berupaya mengurangi penyelesaian perkara anak di pengadilan pidana, dan jika terpaksa dipidana 
penjara, maka pidana tersebut hanya dilakukan sebagai upaya terakhir dan dalam waktu yang singkat.

Menurut Wardaya dan Retnaningrum, sebagaimana dikutip Widodo. (http://id.portalgaruda. org. diakses pada tanggal 5 Maret 2016), dikatakan bahwa kesadaran masyarakat bahwa anak-anak pelaku tindak pidana perlu diperlakukan khusus tidak sebagaimana orang dewasa baru disadari sejak penyelenggaraan peradilan anak kali pertama di Chicago pada 1889. Urgensi pelaksanaan diversi pada perkara anak didasari pada pemikiran berikut. Saat ini ada pergeseran filsafat pemidanaan dari awalnya yang bersifat restitutif (pembalasan) kemudian ditandingi menjadi teori prevensi (tujuan), kemudian muncul teori gabungan, dan akhirnya berkembang pemikiran keadilan restoratif yang mengutamakan pemulihan. Pendekatan restoratif merupakan paradigma baru dalam pemidanaan yang berbeda dengan pendekatan keadilan retributif, baik konsep, orientasi, tujuan maupun mekanisme pencapaiannya. Keadilan retributif lahir sebagai reaksi terhadap beberapa kelemahan pendekatan keadilan retributif.

Perubahan paradigma tentang keadilan dalam hukum pidana merupakan fenomena yang mendunia karena masyarakat semakin menyadari bahwa perlu ada perubahan yang radikal menyangkut penanganan $\mathrm{ABH}$. Sistem peradilan pidana anak yang berlandaskan pada keadilan retributif dan restitutif memberikan kewenangan penuh kepada para penegak hukum tanpa memberikan kesempatan kepada $\mathrm{ABH}$, maupun korbannya untuk menyampaikan versi keadilan yang mereka inginkan. Derajat keadilan bagi korban ditentukan dengan memberikan hukuman penjara bagi pelaku. Hal ini menjadi salah satu faktor meningkatnya tingkat kriminalitas yang dilakukan oleh $\mathrm{ABH}$ karena dipenjara mereka justru dapat mempelajari kejahatan yang belum pernah mereka lakukan sebelumnya dari penghuni penjara lainnya.

Tokoh teori retributif adalah Immanuel Kant (1724-1804) dan Hegel (1770-1831). Pandangan mereka adalah keyakinan mutlak akan kepercayaan pidana, sekalipun sebenarnya pidana tidak berguna. Pandangan diarahkan ke masa lalu dan bukan ke masa depan dan kesalahan telah bisa ditebus dengan menjalani penderitaan. Adapun ciri-ciri pokok dari teori retributif atau teori absolut ini 
diantaranya tujuan pemidanaan hanya untuk pembalasan, hanya pembalasan yang menjadi tujuan utama dan tidak menjadi sarana untuk mencapai tujuan lainnya, misalnya kesejahteraan masyarakat (social welfare). Selain itu, kesalahan moral (moral guilt) merupakan syarat satu-satunya tujuan penjatuhan pidana artinya penjatuhan pidana harus sesuai dengan kesalahan moral pelaku serta pemidanaan melihat ke belakang sebagai suatu pencelaan dan tujuannya tidak untuk memperbaiki, mendidik atau meresosialisasi pelaku kejahatan.

Cessare Beccaria (1738-1794) melakukan kritikan keras terhadap tujuan pemidanaan dalam teori retributif diatas. Beccaria mempertanyakan apakah pemidanaan merupakan sarana yang cocok untuk suatu kejahatan. Apakah pemidanaan seseorang benar-benar berguna dan penting untuk menjaga keamanan dan ketertiban masyarakat dari ancaman kejahatan serta apakah penyiksaan terhadap pelaku akan mencapai keadilan sebagaimana dikedepankan oleh hukum. Berdasarkan hal tersebut diatas, menurut Beccaria tujuan pemidanaan adalah mencegah seseorang untuk melakukan kejahatan dan bukan menjadi sarana balas dendam masyarakat (the purpose of punishment is to deter person from the commission of crime and not to provide social revenge). Oleh karena itu pidana yang kejam tidak membawa manfaat bagi keamanan dan ketertiban masyarakat. Upaya penanggulangan kejahatan menurut Beccaria lebih baik dengan melakukan upaya preventif daripada melakukan pemidanaan.

Di sisi lain Jim Consedine sebagai salah satu pelopor keadilan restoratif berpendapat bahwa konsep keadilan retributif dan restitutif yang berlandaskan hukuman, balas dendam terhadap pelaku, pengasingan dan perusakan harus digantikan oleh keadilan restoratif yang berlandaskan rekonsiliasi, pemulihan korban, integrasi dalam masyarakat, pemaafan dan pegampunan (Dewi dan Syukur 2011: 26).

Selanjutnya Dean E Peachey, dalam Dewi dan Syukur (2011: 27), memberikan penjelasan terkait perbedaan paradigma dalam penanganan $\mathrm{ABH}$ sebagai berikut: 
Tabel 1:

Perbedaan Paradigma dalam Penanganan ABH

\begin{tabular}{|c|c|c|c|c|}
\hline No & Perbedaan & Restitusi & Retribusi & Restorasi \\
\hline 1. & $\begin{array}{l}\text { Landasan } \\
\text { Filosofi }\end{array}$ & $\begin{array}{l}\text { Memperbaiki } \\
\text { kesalahan dengan } \\
\text { mengganti atau } \\
\text { memperbaharui }\end{array}$ & $\begin{array}{l}\text { Mencapai keadilan } \\
\text { dengan memberi } \\
\text { balasan atas } \\
\text { derita/sakit yang } \\
\text { ditimbulkan }\end{array}$ & $\begin{array}{l}\text { Pemberian maaf } \\
\text { sebagai dasar } \\
\text { memperbaiki } \\
\text { hubungan antar } \\
\text { manusia }\end{array}$ \\
\hline 2. & Cara & $\begin{array}{l}\text { Korban } \\
\text { menerima ganti } \\
\text { rugi }\end{array}$ & $\begin{array}{l}\text { Pelaku dijatuhi } \\
\text { hukuman yanng } \\
\text { setimpal atau lebih } \\
\text { berat }\end{array}$ & $\begin{array}{l}\text { Pelaku menyesali } \\
\text { perbuatan, } \\
\text { berjanji tidak } \\
\text { mengulangi } \\
\text { (dengan } \\
\text { memberikan ganti } \\
\text { rugi bila } \\
\text { diperlukan) }\end{array}$ \\
\hline 3. & Fokus & Korban & Pelaku & $\begin{array}{l}\text { Korban dan } \\
\text { pelaku }\end{array}$ \\
\hline
\end{tabular}

Dari uraian di atas dapat disimpulkan bahwa paradigma dalam penanganan $\mathrm{ABH}$ yang menawarkan solusi yang lebih komprehensif baik bagi korban maupun pelaku adalah keadilan restoratif karena mencakup penyadaran perbuatan, pernyataan maaf, pemulihan korban bahkan pemberian ganti kerugian apabila diperlukan. Hal ini tidak terdapat dalam nilai-nilai paradigma dalam keadilan restitutif maupun keadilan retributif.

Nilai-nilai keadilan restoratif memberikan perhatian yang sama kepada korban dan pelaku karenanya otoritas untuk menentukan rasa keadilan ada di tangan para pihak sedangkan negara berfungsi sebagai fasilitator. Dalam hal ini penerapan keadilan restoratif memakai pendekatan respon yang lentur terhadap kejahatan, pelaku dan korban yang memungkinkan penyelesaian kasus secara individual (tidak diajukan ke pengadilan secara formal) juga memakai pendekatan respon atas kejahatan dengan tetap mempertahankan harkat dan martabat setiap orang, membangun saling pengertian dan harmonis melalui pemulihan korban, pelaku dan masyarakat.

Keadilan restoratif juga dapat mengurangi dampak stigmastisasi bagi pelaku, dapat dilakukan sejalan dengan mekanisme tradisional yang masih 
dipertahankan, mengedepankan pemecahan masalah dan sekaligus menemukan akar konflik, keadilan restoratif juga memperhatikan kerugian dan kebutuhan korban, mendorong pelaku untuk melihat lebih dalam mengenai sebab dan akibat perbuatannya, menyadarinya dan bertanggungjawab atas kerugian tersebut. Selain itu, keadilan restoratif juga dapat disesuaikan dengan tradisi hukum, asas dan filosofi setempat dan sistem hukum nasional, serta sangat tepat untuk kasus yang melibatkan anak di bawah umur dengan menempatkan peran masyarakat pada tempat yang penting, bukan hanya untuk mengatasi masalah yang terjadi, tetapi juga untuk mencegah terjadinya kembali tindak pidana di masa depan.

\section{Diversi dan diskresi kepolisian dalam perspektif keadilan restorasi}

Sehubungan kewenangan yang dimiliki polisi, maka dalam penanganan $\mathrm{ABH}$, aparat kepolisian dapat melakukan atau menggunakan kewenangan diskresi dari pada harus melanjutkan proses hukumnya. Dalam hal ini dikenal dengan istilah diskresi kepolisian, yang merupakan kewenangan polisi untuk menghentikan penyidikan perkara dengan membebaskan tersangka ataupun melakukan pengalihan (diversi), dan tujuannya agar anak terhindar dari proses hukum lebih lanjut.

Di Indonesia aparat kepolisian mempunyai kewenangan diskresi, seperti yang diatur dalam Pasal 18 UU No. 2 Tahun 2002, yang menentukan bahwa untuk kepentingan umum, pejabat Polri dalam melaksanakan tugas dan wewenangnya dapat bertindak menurut penilaiannya sendiri. Salah satu kewenangan diskresi ini adalah melalui tindakan diversi dan tentunya tindakan diversi yang dilakukan tidak boleh melanggar aturan hukum yang berlaku.

Dasar hukum bagi aparat kepolisian melakukan tindakan pengalihan (diversi), sejalan dengan ketentuan yang terdapat dalam Pasal 40 ayat (3) Konvensi Hak Anak (KHA), yang menentukan bahwa negara-negara peserta harus berupaya meningkatkan pembentukan hukum, prosedur, kewenangan dan lembaga yang secara khusus berlaku untuk anak-anak yang diduga, disangka, dituduh atau dinyatakan melanggar hukum pidana dan khususnya:

a. Menetapkan usia minimum sehingga anak-anak yang berusia di bawahnya dianggap tidak mempunyai kemampuan untuk melanggar hukum pidana. 
b. Bilamana layak dan diinginkan, melakukan langkah untuk menangani anakanak seperti itu tanpa harus menempuh jalur hukum, dengan syarat bahwa HAM dan perangkat pengamanan hukum sepenuhnya dihormati.

Berdasarkan Resolusi PBB No. 40/33 Tahun 1985 (The Beijing Rules), bagi aparat polisi yang menangani perkara tindak pidana anak juga diberikan kewenangan untuk melakukan pengalihan. Ketentuannya dapat dilihat pada:

a. Butir 6, disebutkan bahwa:

1) Mengingat kebutuhan khusus yang beragam dari anak-anak maupun keragaman langkah yang tersedia, ruang lingkup yang memadai bagi kebebasan anak, untuk membuat keputusan diizinkan pada seluruh tahap proses peradilan bagi anak dan pada tahap-tahap berbeda dari administrasi peradilan bagi anak, termasuk dalam penyidikan, penuntutan, pengambilan keputusan dan pengaturan-pengaturan lanjutannya.

2) Upaya-upaya dilakukan untuk memastikan adanya pertanggungjawaban yang cukup pada seluruh tahap dan tingkat dalam pelaksanaan kebebasan untuk membuat keputusan.

3) Mereka yang melaksanakan kebebasan untuk membuat keputusan, berkualifikasi atau terlatih secara khusus untuk melaksanakannya secara bijaksana dan sesuai dengan fungsi-fungsi serta tugas-tugas mereka.

b. Butir 11, ditegaskan bahwa:

1) Pertimbangan diberikan untuk menangani pelanggar-pelanggar hukum berusia muda tanpa menggunakan peradilan formal oleh pihak berwenang yang berkompeten.

2) Polisi, penuntut umum atau badan-badan lain yang menangani perkaraperkara anak diberikan kuasa untuk memutuskan perkara demikian menurut kebijaksanaan mereka, tanpa menggunakan pemeriksaan awal yang formal, sesuai dengan kriteria yang ditentukan untuk tujuan itu dalam sistem hukum masing-masing dan sesuai dengan prinsip-prinsip yang terkandung dalam peraturan-peraturan ini.

3) Pengalihan apapun yang melibatkan perujukan kepada pelayananpelayanan masyarakat atau pelayanan lain, memerlukan persetujuan anak 
tersebut atau orang tua walinya, dengan syarat keputusan merujuk pada perkara dan tergantung pada kajian pihak berwenang yang berkompeten atas permohonan.

4) Agar lebih mempermudah pelulusan kebebasan membuat keputusan pada perkara-perkara anak, upaya-upaya yang diambil untuk mengadakan persiapan bagi program-program masyarakat, seperti pengawasan dan bimbingan sementara, pemulihan dan pemberian ganti kerugian kepada korban-korban.

Berdasarkan ketentuan ini, maka kepada aparat kepolisian diberikan kewenangan khusus (diskresi) untuk melakukan pengalihan (diversi) yang menjauhkan $\mathrm{ABH}$ dari proses peradilan formal, penahanan ataupun pemenjaraan. Program diversi ini dapat dilakukan dengan berbagai macam cara, antara lain adalah dengan menempatkan $\mathrm{ABH}$ di bawah pengawasan badan-badan sosial tertentu guna membantu anak tersebut memecahkan masalah yang dihadapinya.

Secara khusus, tidak ada ketentuan undang-undang di Indonesia yang menetapkan standar tindakan diversi untuk pelaksanaan penanganan $\mathrm{ABH}$, tetapi merujuk pada ketentuan yang terdapat dalam Pasal 18 UU No. 2 Tahun 2002, maka penanganan $\mathrm{ABH}$ tidak seharusnya dilakukan dengan mengikuti sistem peradilan pidana formal. Dengan kata lain bahwa, sesuai kewenangan yang dimilikinya, maka dalam penanganan $\mathrm{ABH}$, aparat kepolisian dapat lebih leluasa mengambil tindakan berupa tindakan pengalihan (diversi) di luar dari sistem peradilan pidana formal.

Selain itu, berdasarkan Telegram Kabagreskrim Polri No. Pol.: TR/1124/ $\mathrm{XI} / 2006$, tindakan diversi dapat dilakukan dalam bentuk pengembalian kepada orang tua si anak, baik tanpa maupun disertai peringatan informal ataupun melaksanakan mediasi, seperti menjadi perantara guna mengkomunikasikan atau memfasilitasi pemenuhan kebutuhan korban dan perlindungan terhadap $\mathrm{ABH}$ dalam bingkai tujuan menyelesaikan persoalan yang timbul akibat perbuatannya.

Penanganan ABH melalui tindakan diversi sebagai upaya untuk mewujudkan keadilan, walaupun menurut Mochtar Kusumaatmadja dan B. Arief Sidharta (2000: 52) dikatakan bahwa keadilan adalah suatu yang sukar didefinisikan, tetapi 
dapat dirasakan dan merupakan unsur yang tidak dapat dipisahkan dari hukum sebagai perangkat asas dan kaidah yang menjamin adanya keteraturan dan ketertiban dalam masyarakat

Sebenarnya ukuran nilai keadilan dapat dilihat dari dua aspek. Selain aspek idealnya, nilai keadilan mempunyai aspek empiris, artinya bahwa ukuran nilai keadilan dalam konteks hukum (aspek ideal) harus dapat diaktualiasasikan secara konkrit menurut manfaatnya (aspek empiris). Dengan adanya ukuran manfaat nilai keadilan, maka keadilan dapat dipandang menurut konteks empiris (E. Fernando M. Manulang 2007: 100). Berdasarkan pendapat ini, maka dapat dikatakan bahwa ukuran untuk mengatakan bahwa suatu tindakan telah memenuhi nilai keadilan, tidak dapat diukur hanya mengacu pada ketentuan undang-undang, melainkan harus diukur pula berdasarkan nilai keberlakuannya dalam masyarakat.

Hakekat keadilan merupakan penilaian terhadap suatu perlakuan atau tindakan yang mengkajinya dengan suatu norma menurut pandangan subjektif (subjektif untuk kepentingan kelompoknya, golongannya dan sebagainya) yang melebihi norma-norma lain. Dalam hal konsep keadilan ini ada dua pihak yang terlibat, yaitu pihak yang memperlakukan dan pihak yang menerima perlakuan. Pada umumnya keadilan merupakan penilaian yang hanya dilihat dari pihak yang menerima perlakuan saja, padahal keadilan seharusnya dilihat dari kedua belah pihak (Sudikno Mertokusumo 2003: 77-78).

Dalam sistem hukum pidana Indonesia, telah berkembang suatu konsep keadilan yang tidak hanya melihat keadilan itu hanya dari satu sisi saja, melainkan menilainya dari kepentingan berbagai pihak, baik kepentingan si korban, masyarakat maupun kepentingan si pelaku. Keadilan yang dimaksudkan disini bukanlah keadilan yang berarti menjatuhkan hukuman yang sesuai tindakan si pelaku, melainkan suatu keadilan yang dikenal dengan keadilan restorasi.

Tony Marshall (1999:5) sebagaimana dikutip Taufik Hidayat (2005: 26) menyebutkan bahwa keadilan restorasi adalah proses yang melibatkan semua pihak pada kejahatan, khususnya untuk memecahkan secara bersama-sama bagaimana mengatasi akibat dari suatu kejahatan dan implikasinya di masa mendatang. Kelompok Kerja PBB, sebagaimana dikutip oleh Rena Yulia Nuryani 
(2009: 19), menyebutkan bahwa keadilan restorasi sebagai suatu proses yang melibatkan semua pihak yang berhubungan dengan tindak pidana tertentu bersama-sama memecahkan masalah dan memikirkan bagaimana menangani akibat di masa yang akan datang.

Dalam penyelesaian perkara tindak pidana yang menggunakan bentuk pendekatan keadilan restorasi, lebih menekankan kepada keterlibatan langsung pihak-pihak dan menuntut usaha kerjasama dengan masyarakat serta pemerintah untuk menciptakan suatu lingkungan yang harmonis, sehingga korban dan pelaku dapat merekonsiliasi konflik mereka dan menyelesaikan kerugian mereka dan dalam waktu yang bersamaan menimbulkan rasa aman dalam masyarakat (Mudzakir 2005: 26).

Konsep keadilan restorasi memungkinkan korban, pelaku dan komunitas masyarakat untuk terlibat langsung dalam merespon kejahatan. Mereka menjadi sentral dalam proses peradilan pidana, sementara itu negara dan kalangan profesional menjadi fasilitator dari sistem yang mengarah pada pertanggungjawaban pelaku kejahatan, ganti rugi kepada korban dan partisipasi penuh dari korban, pelaku dan masyarakat. Proses pemulihan melibatkan semua pihak yang merupakan dasar untuk mencapai hasil yang restoratif dari perbaikan dan perdamaian (Taufik Hidayat 2005: 26).

Pelaksanaan konsep keadilan restorasi pada dasarnya mengandung 3 (tiga) prinsip pokok, yaitu: pertama, bahwa keadilan membutuhkan orang-orang yang dapat bekerjasama untuk memulihkan orang-orang yang telah menderita, kedua, bahwa yang terlibat secara langsung dan yang terkena kejahatan harus memiliki kesempatan berpartisipasi penuh untuk merespon jika diperlukan, dan ketiga, bahwa peraturan perundang-undangan adalah untuk melindungi kepentingan publik, masyarakat yang membangun serta memelihara perdamaian (Taufik Hidayat 2005: 28).

Pendapat Adrianus Meliala sebagaimana dikutip oleh Poernomo Gontha Ridho (http://www.infoanda.com. diakses pada tanggal 29 Pebruari 2016) menggambarkan konsep restorative justice sebagai upaya penyelesaian konflik dan sekaligus penyembuhan antara pelaku dan korban. Caranya adalah dengan 
mempertemukan atau mengenalkan pelaku dalam satu forum dengan korban ataupun keluarganya untuk menumbuhkan empati di kedua belah pihak. Di Indonesia, seorang pembunuh yang terbukti bersalah dimasukkan ke lembaga pemasyarakatan. Persoalannya selesai sampai di situ, sementara perasaan keluarga korban sendiri dan perasaan pelaku bila melihat derita korban sama-sama tidak tahu. Selain itu, kemungkinan besar pelaku yang sudah dimasukkan ke lembaga pemasyarakatan akan berbuat serupa bila nanti keluar penjara. Dengan konsep restorative justice ini, diharapkan pelaku paham dan sadar bahwa akibat perbuatannya telah membuat orang lain menderita dan pihak korban tidak lagi menyimpan rasa dendam.

Pendapat lain menurut Dadang Sudiadi sebagaimana dikutip oleh Clara Rondonuwu (http://www.media-indonesia.com, diakses pada tanggal 29 Pebruari 2016), menjelaskan bahwa tanpa restorative justice, mengadili anak sama saja menghukum anak. Bukan membina mereka. Padahal, keadilan untuk perkara anak cukup banyak yang bisa diselesaikan hanya dengan mempertemukan pelaku dengan yang dirugikan atau disebut restorasi, karena pendekatan peradilan konvensional yang ada sekarang cenderung menjatuhkan sanksi pidana penjara ketimbang sanksi tindakan. Lebih lanjut menurut Dadang Sudiadi, bahwa konsep restorative justice sesungguhnya bukan hal baru di Indonesia. Hukum adat di beberapa daerah sudah menerapkannya. Antara lain model tepung tawar yang diadopsi masyarakat Sumatera Utara, Bengkulu dan Sumatra Selatan. Melalui cara ini, anak yang menjadi pelaku pidana datang menghadap keluarga korban. Diadakan pesta, dilakukan permintaan maaf dan acara makan-makan. Kalau korban sampai meninggal, seperti korban tabrakan, maka keluarga pelaku menjadikan anak korban sebagai anak angkat.

Sebenarnya di Indonesia banyak hukum adat konsep keadilan restorasi (restorative justice) yang dapat diadopsi, namun keberadaannya kurang diakui atau tidak dikodifikasikan dalam hukum nasional. Paktanya hukum adat dapat menyelesaikan konflik yang muncul di masyarakat dan memberikan kepuasan pada pihak yang berkonflik. Oleh sebab itu, berkembanglah ide restorative justice sebagai kritik atas penerapan sistem peradilan pidana dengan pemenjaraan yang 
dianggap tidak efektif dalam menyelesaikan konflik sosial. Penyebabnya, pihak yang terlibat dalam konflik tersebut tidak dilibatkan dalam penyelesaian konflik. Korban tetap saja menjadi korban, pelaku yang dipenjara juga memunculkan persoalan baru bagi keluarga dan sebagainya.

\section{Pelaksanaan diversi dalam sistem peradilan pidana anak}

Kata diversi berasal dari bahasa Inggris diversion yang bermakna penghindaran atau pengalihan (Dewi dan Syukur 2011: 51). Kata ini menjadi kata serapan yang telah disesuaikan berdasarkan Pedoman Umum Bahasa Indonesia Yang Disempurnakan dan Pedoman Pembentukan Istilah menjadi diversi. Pemakaian kata diversion pertama kali dikemukakan dalam laporan pelaksanaan pengadilan anak yang disampaikan oleh Presiden Komisi Pidana Anak Australia (President's Crime Commission) di Amerika Serikat pada tahun 1990 (Cunneen dan White 2002: 1).

Bynum and Thompson dalam bukunya Juvenile Delinquency: A Socialogical Approach menyampaikan pengertian dari diversi yaitu: Diversion is an attempt to divert, or channel out, youthful offenders from the juvenile justice system (diversi adalah sebuah tindakan atau perlakuan untuk mengalihkan/ menempatkan pelaku tindak pidana anak keluar dari sistem peradilan pidana). (Bynum dan Thompson 1996: 43). Pasal 1 angka (7) UU SPPA menyebutkan bahwa diversi adalah pengalihan penyelesaian perkara anak dari proses peradilan pidana ke proses di luar peradilan anak. Pengaturan diversi dalam UU SPPA bertujuan agar $\mathrm{ABH}$ tidak terstigmatisasi akibat proses peradilan yang harus dijalaninya. Mekanisme diversi diberlakukan pada tingkat penyidikan, penuntutan dan pemeriksaan perkara anak di pengadilan negeri. Hal ini dilaksanakan dengan harapan dapat mengurangi keterlibatan anak dalam suatu proses peradilan.

McCarthy dan McCharty sebagaimana dikutip Dewi dan Syukur (2011: 52), menjelaskan tujuan program diversi, sebagai berikut: 
Tabel 2:

Tujuan Program Diversi

\begin{tabular}{lll}
\hline No & Bagi Pelaku & Bagi Korban dan Masyarakat \\
\hline 1. $\begin{array}{l}\text { Melakukan evaluasi dan } \\
\text { intervensi segera setelah pelaku } \\
\text { teridentifikasi. }\end{array}$ & $\begin{array}{l}\text { Mengurangi beban kerja sistem } \\
\text { peradilan pidana. }\end{array}$ \\
2. $\begin{array}{l}\text { Menyediakan program selain yang } \\
\text { ditawarkan sistem peradilan. }\end{array}$ & $\begin{array}{l}\text { Mencapai restitusi atau pemerhatian } \\
\text { masalah korban secara lebih cepat. } \\
\text { Meminimalisasi gangguan sosial, } \\
\text { 3embuat sumber daya sistem } \\
\text { emosional dan ekonomi yang } \\
\text { dihadapi tertuduh pelaku tindak } \\
\text { pidana. }\end{array}$ & $\begin{array}{l}\text { peradilan pidana lebih berfokus pada } \\
\text { tindak pidana yang lebih berat. }\end{array}$ \\
$\begin{array}{l}\text { Menghindari stigma dan } \\
\text { kebebasan pribadi bagi pelaku. } \\
\text { Menyediakan lingkungan yang } \\
\text { tidak koersif terhadap sisa masa } \\
\text { pelayanan program diversi bagi } \\
\text { pelaku. }\end{array}$ & $\begin{array}{l}\text { Mengurangi biaya untuk upaya } \\
\text { penurunan tindak pisana. }\end{array}$ \\
\hline
\end{tabular}

Selanjutnya UU SPPA menguraikan tujuan dari diversi diantaranya untuk mencapai perdamaian antara korban dan anak, menyelesaikan perkara anak di luar proses peradilan, menghindarkan anak dari perampasan kemerdekaan, mendorong masyarkat untuk berpartisipasi serta dapat menanamkan rasa tanggung jawab kepada anak. Proses diversi wajib memperhatikan kepentingan korban, kesejahteraan dan tanggung jawab anak, penghindaran stigma negatif, penghindaran pembalasan, keharmonisan masyarakat serta memperhatikan kepatutan, kesusilaan dan ketertiban umum.

Pelaksanaan diversi dalam hal ini hanya dapat dilaksanakan kepada anak yang diancam dengan pidana penjara di bawah 7 (tujuh) tahun dan bukan merupakan pengulangan tindak pidana (residive). Hal ini perlu menjadi fokus perhatian untuk dapat memperkecil potensi pemaksaan dan intimidasi pada semua tahap proses diversi. Anak tidak boleh merasa tertekan atau ditekan untuk menyetujui program diversi. Pelaksanaan diversi harus mendapatkan persetujuan korban dan/atau keluarga anak korban serta kesediaan anak dan keluarganya, kecuali untuk tindak pidana yang berupa pelanggaran, tindak pidana ringan, 
tindak pidana tanpa korban atau nilai kerugian korban tidak lebih dari nilai upah minimum provinsi setempat.

Pasal 3 Peraturan Mahkamah Agung RI Nomor 4 Tahun 2014 tentang Pedoman Pelakanaan Diversi Dalam Sistem Peradilan Pidana Anak juga menegaskan pemberlakuan diversi terhadap anak yang didakwa dengan tindak pidana yang diancam dengan pidana penjara 7 (tujuh) tahun atau lebih dalam bentuk surat dakwaan subsidiaritas, alternatif, kumulatif maupun kombinasi (gabungan). Pelaksanaan diversi ini hanya dapat diberlakukan terhadap anak yang telah berumur 12 (dua belas) tahun tetapi belum berumur 18 (delapan belas) tahun atau telah berumur 12 (dua belas) tahun meskipun pernah kawin tetapi belum berumur 18 (delapan) belas tahun, yang diduga melakukan tindak pidana. Namun demikian, dalam hal anak belum berumur 12 (dua belas) tahun tetapi melakukan atau diduga melakukan tindak pidana, maka Penyidik, Pembimbing Kemasyarakatan dan Pekerja Sosial Profesional dapat mengambil keputusan untuk menyerahkannya kembali kepada orang tua/wali atau dapat mengikutsertakannya dalam program pendidikan, pembinaan dan pembimbingan di instansi pemerintah atau LPKS di instansi yang menangani bidang kesejahteraan sosial, baik di tingkat pusat maupun daerah paling lama 6 (enam) bulan.

Pelaksanaan diversi ini wajib diupayakan pada tingkat penyidikan, penuntutan dan pemeriksaan perkara anak di pengadilan negeri. Penyidik, penuntut umum dan hakim dalam melakukan proses diversi harus mempertimbangkan beberapa hal di antaranya:

a. Kategori tindak pidana;

b. Umur anak;

c. Hasil penelitian kemasyarakatan; dan

d. Dukungan lingkungan keluarga dan masyarakat.

Proses diversi ini dilakukan melalui musyawarah diversi dan dilaksanakan dalam jangka waktu paling lama 30 (tiga puluh) hari terhitung sejak tanggal dimulainya diversi. Pelaksanaan diversi melibatkan penegak hukum dalam tiap proses peradilan (penyidik, penuntut umum, hakim), anak dan/atau orang tua/ wali, korban atau anak korban dan/atau orang tua/wali, pembimbing 
kemasyarakatan serta pekerja sosial profesional. Selain itu, dalam hal dikehendaki oleh anak dan/atau orang tua/wali, pelaksanaan musyawarah diversi dapat melibatkan masyarakat yang terdiri dari tokoh agama, guru, tokoh masyarakat, pendamping dan/atau advokat atau pemberi bantuan hukum. Setelah dilaksanakannya musyawarah diversi maka hasil kesepakatan diversi dapat berbentuk:

a. Perdamaian dengan atau tanpa ganti rugi;

b. Penyerahan kembali kepada orang tua/wali;

c. Keikutsertaan dalam pendidikan atau pelatihan di lembaga pendidikan atau LPKS paling lama 3 (tiga) bulan;

d. Pelayanan masyarakat.

Hasil kesepakatan diversi ini dituangkan dalam bentuk Surat Kesepakatan Diversi, serta hasil kesepakatan diversi harus ditetapkan oleh Ketua Pengadilan Negeri di wilayah tempat terjadinya perkara atau di wilayah tempat kesepakatan diversi dibuat.

Pelaksanaan diversi dapat menjadi bentuk restoratif justice apabila pelaksanaan diversi ini dapat mendorong anak untuk bertanggung jawab atas perbuatannya, memberikan kesempatan bagi anak untuk mengganti kesalahan yang dilakukan dengan berbuat kebaikan bagi si korban, memberikan kesempatan bagi si korban untuk ikut serta dalam proses, memberikan kesempatan bagi si anak untuk dapat mempertahankan hubungan keluarga serta memberikan kesempatan bagi rekonsiliasi dan penyembuhan dalam masyarakat yang dirugikan oleh tindak pidana.

Pelaksanaan metode ini dilaksanakan agar tercapai kesejahteraan anak dengan berdasar prinsip kepentingan terbaik bagi anak. Dengan kata lain, diversi tersebut berdasarkan pada perlindungan anak dan pemenuhan hak-hak anak (protecton child and fullfilment child rights based approuch), tetapi proses diversi ini dapat berjalan dengan baik apabila semua pihak melakukan perannya masingmasing dimulai dari orang tua, para penegak keadilan begitu juga dengan masyarakat. Pelaksanaan diversi merupakan tanggung jawab semua pihak sehingga anak sebagai korban maupun sebagai pelaku mendapat yang terbaik serta penekanan akan pemulihan kembali hubungan pada keadaan semula dan 
bukan pembalasan dapat terlaksana dengan baik tanpa merugikan salah satu pihak dan disisi lain menguntungkan pihak yang lain.

Penanganan $\mathrm{ABH}$ semestinya tidak dilakukan dengan pendekatan retrebutif, melainkan melalui cara-cara pendekatan yang lebih mendidik dan memenuhi rasa keadilan, yaitu melalui pendekatan keadilan restorasi (restorative justice). Alasannya bahwa ABH sendiri tidak jarang sekaligus merupakan korban tindak pidana, terlebih lagi jika mereka adalah anak-anak yang masih mempunyai masa depan panjang. Sebagai penegak hukum, aparat Kepolisian dituntut untuk mampu melaksanakan penanganan $\mathrm{ABH}$ dengan pendekatan keadilan restorasi, sehingga $\mathrm{ABH}$ tersebut tidak harus selalu dihukum berdasarkan ketentuan yang berlaku dalam sistem peradilan pidana formal.

Penanganan $\mathrm{ABH}$ tanpa harus melalui sistem peradilan pidana, merupakan kewenangan diskresi kepolisian sebagaimana diatur dalam Pasal 18 UU No. 2 Tahun 2002. Oleh sebab itu, dalam upaya penanganan ABH, aparat kepolisian diperkenankan untuk mengambil tindakan diversi (pengalihan) penyelesaian perkara di luar sistem peradilan pidana formal yang ada. Kewenangan diskresi untuk melaksanakan diversi ini juga didasarkan pada Resolusi PBB No. 40/33 Tahun 1985 (The Beijing Rules) dan sejalan pula dengan Telegram Kabagreskrim Polri No. Pol.: TR/1124/ XI/2006.

Berdasarkan ketentuan tersebut maka hukum akan lebih memenuhi rasa keadilan, jika dalam penanganan ABH dapat memberikan manfaat kepada banyak pihak, tidak hanya bagi si pelaku, tetapi juga bagi masyarakat luas, karena tujuan hukum juga untuk memberikan manfaat dalam menghasilkan kesenangan atau kebahagiaan yang terbesar bagi jumlah orang yang terbanyak. Aparat kepolisian yang dalam fungsi dan tugasnya sebagai aparatur penegak hukum dan sekaligus pelindung dan pengayom masyarakat, dituntut untuk mampu melakukan pendekatan keadilan restorasi dalam penanganan $\mathrm{ABH}$, sehingga dapat memperbaiki sistem peradilan yang sudah ada sebelumnya. Artinya lebih bersifat merestorasi atau memperbaiki, yang dapat mengubah pendekatan konsep keadilan yang sesuai dalam penyidikan perkara-perkara pidana anak. 


\section{Simpulan dan Saran}

\section{Simpulan}

Penerapan diversi dalam sistem peradilan pidana anak sebagaimana telah diamanatkan oleh UU SPPA merupakan alternatif penyelesaian terbaik bagi $\mathrm{ABH}$ karena dalam penerapannya lebih mengutamakan prinsip kepentingan terbaik bagi anak baik dari segi fisik maupun psikologis anak. Dalam hal ini kasus ABH yang dibawa dalam proses peradilan adalah kasus yang serius saja dan penghukuman merupakan jalan terakhir dengan tetap memperhatikan serta tidak mengabaikan hak-hak anak. Pelaksanaan diversi juga wajib dilaksanakan dalam setiap tingkatan pemeriksaan baik penyidikan, penuntutan sampai dengan pemeriksaan di persidangan, tetapi proses penerapan diversi ini tidak terlepas dari peran keluarga, pihak sekolah dimana sebagian besar waktu anak dihabiskan di lingkungan sekolah serta lingkungan sosial masyarakat. Hal ini disebabkan karena tumbuh kembang anak setelah selesainya proses hukum yang melibatkan anak juga turut dipengaruhi oleh penerimaan dari lingkungan sekitar.

Kasus ABH yang dibawa dalam proses peradilan adalah kasus kasus yang serius saja, itupun harus selalu mengutamakan prinsip kepentingan terbaik bagi anak, serta proses penghukuman adalah jalan terakhir dengan tetap tidak mengabaikan hak hak anak. Diluar itu kasus kasus anak dapat diselesaikan melalui mekanisme non formal yang didasarkan pada pedoman yang baku. Bentuk penanganan non formal dapat dilakukan dengan diversi atau restorative justice yang dapat diselesaikan dengan mewajibkan anak yang berhadapan dengan hukum untuk mengikuti pendidikan atau pelatihan pada lembaga tertentu, ataupun jika terpaksa terjadi penghukuman hak hak anak tidak boleh diabaikan. Sehingga pada akhirnya penanganan nonformal dapat terlaksana dengan baik jika diimbangi dengan upaya menciptakan sistem peradilan yang kondusif.

\section{Saran}

Untuk dapat lebih memaksimalkan penerapan diversi sebagai perwujudan keadilan restoratif maka menurut hemat penulis diperlukan adanya komitmen yang kuat dari para penegak hukum dalam menangani $\mathrm{ABH}$. Hal ini dapat dilakukan dengan membentuk tim khusus dalam penanganan $\mathrm{ABH}$ dalam setiap 
tingkatan pemeriksaan, yang mana tim ini harus diberi pendidikan dan pelatihan sertifikasi secara optimal dan berkesinambungan mengenai penerapan diversi. Pendidikan dan pelatihan ini tidak hanya diberikan kepada Hakim Anak yang menangani perkara tetapi juga diberikan kepada Penyidik serta Penuntut Umum karena proses diversi wajib dilakukan di tiap tingkatannya. Selain itu juga disarankan agar guru bimbingan konseling yang ada di sekolah mendapatkan pelatihan khusus terkait penangangan anak yang bermasalah dengan hukum. 


\section{DAFTAR PUSTAKA}

\section{Buku:}

Bambang Sunggono. 1998. Metodologi Penelitian Hukum. Cetakan Kedua. Jakarta: RajaGrafindo Persada.

Bynum, Jack E. dan William E Thompson. 1996. Juvenile Delinquency: A Sociologcal Approach. Boston Cunneen: Allyn and Bacon.

Chris dan Rob White. 2002. Juvenile Justice: Youth and Crime in Australia. Melbourne: Oxford University Press.

Consedine, Jim. 1995. Restorative Justice: Healing the Effects of Crime. Lyttelton: Ploughshares Publications.

Dewi, DS dan Fatahillah A Syukur. 2011. Mediasi Penal: Penerapan Restorative Justice di Pengadilan Anak Indonesia. Depok: Indie Publishing.

Farouk Muhammad dan H. Djaali. 2005. Metodologi Penelitian Sosial, Edisi Revisi. Jakarta: PTIK Press dan Restu Agung.

Iskandar Hoesin. 2006. Perlindungan Anak dari Perspektif Hak Asasi Manusia, Jakarta: KPAI.

Majda El Muhtaj. 2009. Dimensi-Dimensi HAM Mengurai Hak Ekonomi, Sosial dan Budaya. Jakarta: Rajawali Pers.

Manulang, E. Fernando. 2007. Menggapai Hukum Berkeadilan, Tinjauan Hukum Kodrat dan Antinomi Nilai. Jakarta: Kompas Media Nusantara.

Marbun, Rocky. 2015. Sistem Peradilan Pidana Indonesia: Suatu Pengantar. Malang: Setara Press.

Mochtar Kusumaatmadja dan B. Arief Sidharta. 2000. Pengantar Ilmu Hukum, Suatu Pengenalan Pertama Ruang Lingkup Berlakunya Hukum. Buku I. Bandung: Alumni.

Soerjono Soekanto. 1986. Pengantar Penelitian Hukum. Cetakan Ketiga. Jakarta: UI-Press.

Soerjono Soekanto dan Sri Mamudji. 2003. Penelitian Hukum Normatif, Suatu Tinjauan Singkat. Cetakan Keenam. Jakarta: RadaGrafindo Persada.

\section{Laporan Penelitian/Makalah:}

Mualimin. 2013. "Hak Atas Pendidikan bagi Anak Berkonflik dengan Hukum dalam Proses Peradilan". Proseding, disampaikan dalam Seminar Pemenuhan Hak Atas Pendidikan bagi Anak Berkonflik dengan Hukum dalam Proses Peradilan di Provinsi Banten. Jakarta. 
Mudzakir. 2005. "Viktimologi Studi Kasus di Indonesia", Makalah, disampaikan pada Penataran Hukum Pidana dan Kriminologi Ke-XI, Surabaya.

Rena Yulia Nuryani. 2009. "Restorative Justice Sebagai Alternatif Perlindungan Hukum Terhadap Korban Kekerasan Dalam Rumah Tangga”, Tesis, Program Pascasarjana Universitas Islam Bandung, Bandung.

Taufik Hidayat. 2005. Taufik Hidayat, "Restorative Justice Sebuah Alternatif", dalam Jurnal Restorasi, Edisi IV, Volume 1.

\section{Internet:}

Clara Rondonuwu. "Peradilan Anak Sarat Pelanggaran", http://www.mediaindonesia.com., diakses tanggal 29 Pebruari 2016.

LPKA. "Jawaban Negara Untuk Anak yang Berhadapan dengan Hukum", http:// www.kemenkumham.go.id. diakses tanggal 23 September 2015.

Poernomo Gontha Ridho. "Indonesia Bisa Terapkan Sanksi Pidana Tanpa Penjara", http://www.infoanda.com., diakses tanggal 29 Pebruari 2016.

Widodo. "Diversi dan Keadilan Restoratif dalam Sistem Peradilan Pidana Anak di Indonesia: Urgensi dan Implikasinya". http://id.portalgaruda.org. diakses pada tanggal 5 Maret 2016.

\section{Peraturan Perundang-undangan:}

Republik Indonesia, Undang-undang Nomor 2 Tahun 2002 tentang Kepolisian Negara Republik Indonesia.

Republik Indonesia, Undang-undang Nomor 11 Tahun 2012 tentang Sistem Peradilan Pidana Anak.

Republik Indonesia, Undang-undang Nomor 35 Tahun 2014 tentang Perubahan Undang-undang Nomor 23 Tahun 2002 tentang Perlindungan Anak.

Republik Indonesia, Peraturan Pemerintah Nomor 65 Tahun 2015 tentang Pedoman Pelaksanaan Diversi dan Penanganan Anak yang Belum Berumur 12 (Dua Belas) Tahun.

Republik Indonesia, Peraturan Mahkamah Agung Nomor 4 Tahun 2014 tentang Pedoman Pelaksanaan Diversi dalam Sistem Peradilan Pidana Anak. 


\section{BIODATA PENULIS}

$\begin{array}{ll}\text { Nama } & : \text { Kristina Agustiani Sianturi, S.H } \\ \text { Pekerjaan } & : \text { Kantor Wilayah Kementerian Hukum dan HAM Sumatera } \\ & \text { Utara } \\ \text { Jabatan } & : \text { Staf Bidang Hukum } \\ \text { Nomor HP } & : \text { 081264166152 } \\ \text { E-mail } & : \text { tina_pcsharoon@yahoo.com } \\ \text { Alamat Kantor } & : \text { Jl. Putri Hijau No. 4A, Medan }\end{array}$ 